ISSN 0258-7122

Bangladesh J. Agril. Res. 33(3) : 399-408, September 2008

\title{
EFFECT OF WATER MANAGEMENT AND WEED CONTROL TREATMENTS ON THE PERFORMANCE OF TRANSPLANTED AMAN RICE
}

\author{
M. H. KABIR ${ }^{1}$, M. N. BARI ${ }^{2}$, M. MOYNUL HAQUE ${ }^{3}$, \\ G. J. U. AHMED ${ }^{4}$ AND A. J. M. S. ISLAM ${ }^{5}$
}

\begin{abstract}
A study was conducted from June to December 2003 to assess weed dynamics and yield performance of transplanted aman rice (cv. BRRI Dhan39) in different weed control treatments e.g. two hand weedings at 15 and 40 DAT; Weeding by BRRI Weeder at 20 and 40 DAT; Rifit 500EC @ 1L/ha at 7 DAT; Rifit 500EC @ 1 L/ha at 7 DAT and one hand weeding at 40 DAT; Butachlor $5 \mathrm{G}$ @ 2 kg/ha at 7 DAT; Butachlor 5G @ $2 \mathrm{~kg} / \mathrm{ha}$ at 7 DAT and one hand weeding at 40 DAT along with weed free and unweeded check under both good and poor water management practices. Weed density, weed biomass and weed control efficiency were significantly influenced by different weed control treatments under both water management practices. Other than weed free treatment, Butachlor 5G @ 2 kg/ha applied at 7 DAT along with one hand weeding at 40 DAT showed the best performance under good water management with minimum weed density $\left(16 \mathrm{~g} / \mathrm{m}^{2}\right)$ as well as weed biomass $\left(9.27 \mathrm{~g} / \mathrm{m}^{2}\right)$ and the highest weed control efficiency (82.57\%). Yield and yield components were also significantly influenced by different weed control treatments and water management. The highest grain yield (5.22 t/ha) was obtained under good water management in weed free treatment followed by Butachlor 5G @ 2 kg/ ha and one hand weeding (4.96 t/ha) under same water management. Results revealed that integration of approaches, particularly Butachlor application along with one manual weeding accompanied by proper water management might be the best option to combat weed problems as well as to obtain satisfactory grain yield in transplanted aman rice.
\end{abstract}

Key Words: Transplanted aman rice, water management, weed control treatment and yield.

\section{Introduction}

The yield of transplanted aman rice in Bangladesh is much lower than that of transplanted rice in other rice growing countries. Among the various factors, severe weed infestation is the most important for such low yield (Mamun, 1988). Many investigators have reported a great loss in the rice yield due to weed

\footnotetext{
${ }^{1}$ Senior Scientific Officer, Adaptive Research Division, BRRI, Gazipur-1701, ${ }^{2 \& 3}$ Associate, Professor, Agronomy Department BSMRAU, Gazipur-1706, ${ }^{4}$ Chief Scientific Officer, Agronomy Division, BRRI, Gazipur-1701, ${ }^{5}$ Professor, Soil Science Department, BSMRAU, Gazipur 1706, Bangladesh.
} 
infestation from different parts of the world (Nandal and Singh, 1994). Mamun (1990) reported that weed growth reduced the grain yield by $68-100 \%$ for direct seeded aus rice, $14-48 \%$ for aman rice and $22.36 \%$ for modern boro rice. Therefore, proper weed management is essential for satisfactory rice production in Bangladesh. Weed free period during the critical period of competition is essential for obtaining optimum rice yield. This can be achieved by removing the weeds by mechanical, cultural or chemical means or by their combinations. Subsistence farmers in Bangladesh spend more time and energy on weed control than any other aspects of rice cultivation. Herbicidal weed control methods offer an advantage to save labour and money, as a result, regarded as cost effective (Ahmed et al., 2000). Chemical weed control has been gaining popularity in Bangladesh in recent years (Hossain, 2006) leading to high growth rate in herbicide use in rice cultivation (BBS, 2005). The main reasons are scarcity of labour during peak growing season, and also lower weeding cost by using herbicides. A number of studies (e.g. Mandal et al., 1995; Gill et al., 1992; Panwar et al., 1992) showed that weed control through both traditional and chemical methods influence crop growth and yield attributes of rice. In some cases, however, phytotoxicity by herbicides was observed which eventually led to lower yield performance (Islam, 2001; Rahman, 2001; Mandal et al., 1995). Thus, the appropriate weeding practices need to be adopted by the farmers with a view to reducing weed infestation and maximizing rice yield.

Therefore, the present study was undertaken to see the effect of different weed control treatments either alone or in combination under different water management practices on weed infestation and yield performance of transplanted aman rice.

\section{Materials and Method}

The experiment was conducted at the Agronomy Field Laboratory, Bangabandhu Sheikh Mujibur Rahman Agricultural University (BSMRAU), Gazipur during the period from June to December 2003. BRRI Dhan39, a modern transplanted aman rice variety, was used as the test crop. The experiment was replicated thrice in a split-plot design assigning water management in the main plot and weed control treatments in the sub plots. Unit plot size was $5 \mathrm{~m} \times 4 \mathrm{~m}$. The experiment consisted of two factors. Factor (A) was Water management i.e. $\left(\mathrm{W}_{1}\right)$ Good water management- where at least $5 \mathrm{~cm}$ water depth was maintained through proper levee management and irrigation; and $\left(\mathrm{W}_{2}\right)$ Poor water management- where no definite water depth was maintained throughout the growing perod. Factor (B) was different weed control treatments i.e. $\left(T_{1}\right)$ - No weeding (control), $\left(T_{2}\right)$ - Weed 
free where weeds were completely removed from the plot at 10 days interval until harvest, $\left(\mathrm{T}_{3}\right)$ - two hand weedings at 15 and 40 days after transplanting (DAT), $\left(\mathrm{T}_{4}\right)$ - Two weedings by BRRI Weeder at 20 and 40 DAT, $\left(\mathrm{T}_{5}\right)$ - Herbicide Rifit 500EC @ 1L/ha at 7 DAT, $\left(\mathrm{T}_{6}\right)$-Rifit 500EC @ $1 \mathrm{~L} /$ ha at 7 DAT and one hand weeding at $40 \mathrm{DAT}$, ( $\left.\mathrm{T}_{7}\right)$ - Butachlor 5G @ $2 \mathrm{~kg} / \mathrm{ha}$ at $7 \mathrm{DAT},\left(\mathrm{T}_{8}\right)$ Butachlor $5 \mathrm{G} 2 \mathrm{~kg} / \mathrm{ha}$ at $7 \mathrm{DAT}$ and one hand weeding at $40 \mathrm{DAT}$, respectively. Fertilizers were applied to the plots as N-P-K-S-Zn @ 70-22-35-10-2.3 kg/ha from Urea, TSP, MP, Gypsum and Zinc sulphate, respectively. The whole amount of $\mathrm{P}, \mathrm{K}, \mathrm{S}$ and $\mathrm{Zn}$ were applied as basal dose during final land preparation. N was top-dressed in three equal installments at 20, 40 and 55 DAT, respectively. Thirty-day old rice seedlings were transplanted on 26 July 2003 maintaining $20 \mathrm{~cm} \times 20 \mathrm{~cm}$ spacing. The crops were kept under constant observation from transplanting till harvesting. Harvesting was done on 27 October 2003. Plant protection and other necessary cultural operations were done as and when required.

The data on weed infestation and weed density were collected from each unit plot at 30, 60, 90 DAT and at harvest. A quadrate of $0.25 \mathrm{~m}^{2}$ was placed randomly at three different spots outside an area of $12 \mathrm{~m}^{2}$ in the middle of the plot. The infesting species of weeds within each quadrate were identified and their number was counted species-wise. The average number of three samples was then multiplied by 4 to obtain the weed density per $\mathrm{m}^{2}$. Later degree of weed infestation (DWI) was calculated by using the following formula:

DWI $(\%)=\frac{\text { No. of population of individual weed species }\left(\text { No. } / \mathrm{m}^{2}\right)}{\text { Total no. of infesting weed species }\left(\text { No. } / \mathrm{m}^{2}\right)} \times 100$

The weeds inside each quadrate were uprooted, cleaned and separated species-wise. The collected weeds were first dried in the sun and then in an electric oven for 72 hours maintaining a constant temperature of $80^{\circ} \mathrm{C}$. After drying, weight of each species was taken and expressed in $\mathrm{g} / \mathrm{m}$.

Weed control efficiency was calculated with the following formula:

Weed control efficiency $($ WCE $)=\frac{\text { DMC }- \text { DMT }}{\text { DMC }} \times 100$

Where,

DMC $=$ Weed dry matter production in unweeded treatment

DMT $=$ Weed dry matter production in weed control treatment 
An area of $4 \mathrm{~m}^{2}$ including the crop sampling zone were harvested for measurements of grain and straw yields. The harvested crops were threshed, cleaned, dried, weighed and data were recorded on (i) effective tillers/hill (ii) filled grains/panicle; (iii) unfilled grains/panicl; (iv) 1000-grain weight (g); (v) grain yield (t/ha); and (vi) straw yield (t/ha).

The data were compiled and put under analysis of variance following the experimental design with the help of the computer package MSTAT-C. Later the means were separated through LSD test. Only interaction data were provided in the Tables.

\section{Results and Discussion}

\section{Weed infestation in transplanted aman rice}

\section{Weed species}

Eleven different weed species belonging to five families were found to infest the experimental crop (Table 1). Among those, three were grasses, five were sedges and three were broad-leaved. The most important weed species throughout the growing season were Fimbristylis miliacea, Scirpus mucronatus, and Sphenoclea zeylanica having higher degree of infestation.

Table 1. Weed species infesting the experimental plots of transplanted aman rice (cv. BRRIdhan39).

\begin{tabular}{lllll|l|l}
\hline Sl. & Local name & \multicolumn{1}{c|}{ Scientific name } & \multicolumn{1}{c}{ Family } & $\begin{array}{c}\text { Life } \\
\text { cycle }\end{array}$ & Morphology & DWI \\
\hline 1. & Jaina & Fimbristylis miliacea & Cyperaceae & Annual & Sedge & 29.67 \\
2. & Chechra & Scirpus mucronatus & Cyperaceae & Perennial & Sedge & 19.35 \\
3. & Zheelmarich & Sphenocleazeylanica & Sphenocleaceae & Annual & Broadleaf & 15.83 \\
4. & Pani long & Ludwigia octovalvis & Onagraceae & Annual & Broadleaf & 7.22 \\
5. & Pani kachu & Monochoria vaginalis & Pontederiaceae & Annual & Broadleaf & 6.66 \\
6. & Fulka ghas & Leptochloa chinensis & Graminae & Annual & Grass & 5.61 \\
7. & Chota chech & Cyperus dfformis & Cyperaceae & Annual & Sedge & 4.55 \\
8. & Baro Shayma & $\begin{array}{l}\text { Echinochloa } \\
\text { crussgalli }\end{array}$ & Graminae & Annual & Grass & 3.78 \\
9. & Baro Chech & Cyperus iria & Cyperaceae & Annual & Sedge & 2.83 \\
10. & Mutha & Cyperus rotundus & Cyperaceae & Perennial & Sedge & 2.44 \\
11. & Araji & Leersja hexandra & Graminae & Perennial & Grass & 2.06 \\
\hline
\end{tabular}

Water management practices influenced weed infestation considerably, and it was manifested in both density as well as biomass of weeds (Table 2). Good water management contributed to lesser weed growth resulting in lesser weed density as well as biomass irrespective of treatment. It was, however, 
supplemented by weed control treatments, which ultimately influenced weed control efficiency. Again, considerable differences existed between weed control treatments (Table 2). There was no weed growth in weed free treatment at early crop growth stage, however, negligible weed growth was noticed at later stages. This resulted in the lowest weed density in this treatment throughout the season. weed biomass, the lower the WCE irrespective of treatment. Apart from the weed free condition, the highest WCE was observed in the plots receiving Butachlor $5 \mathrm{G} 2 \mathrm{~kg} / \mathrm{ha}$ accompanied by one hand weeding at $40 \mathrm{DAT}$. Data revealed that irrespective of treatment, weed infestation increased at the end of the season leading to lesser weed control efficiency. It might be due to reduction in the toxicity of the applied chemicals at later growth stages resulting in higher weed

Table 2. Weed density, weed biomass and weed control efficiency as affected by water management and weed control treatments in transplanted aman rice.

\begin{tabular}{|c|c|c|c|c|c|c|c|c|c|c|c|c|c|}
\hline \multirow{2}{*}{$\begin{array}{c}\text { Water } \\
\text { manag- } \\
\text { ement }\end{array}$} & \multirow{2}{*}{$\begin{array}{c}\text { Weed } \\
\text { control } \\
\text { treatment }\end{array}$} & \multicolumn{4}{|c|}{ Weed density (no./m²) } & \multicolumn{4}{|c|}{ Weed biomass $\left(\mathrm{g} / \mathrm{m}^{2}\right)$} & \multicolumn{4}{|c|}{ Weed control efficiency (\%) } \\
\hline & & $\begin{array}{c}30 \\
\mathrm{DAT}\end{array}$ & $\begin{array}{c}60 \\
\text { DAT }\end{array}$ & $\begin{array}{c}90 \\
\text { DAT }\end{array}$ & $\begin{array}{c}\text { At } \\
\text { harvest }\end{array}$ & $\begin{array}{c}30 \\
\text { DAT }\end{array}$ & $\begin{array}{c}60 \\
\text { DAT }\end{array}$ & $\begin{array}{c}90 \\
\text { DAT }\end{array}$ & $\begin{array}{c}\text { At } \\
\text { harvest }\end{array}$ & $\begin{array}{c}30 \\
\text { DAT }\end{array}$ & $\begin{array}{c}60 \\
\mathrm{DAT}\end{array}$ & $\begin{array}{c}90 \\
\mathrm{DAT}\end{array}$ & $\begin{array}{c}\text { At } \\
\text { harvest }\end{array}$ \\
\hline \multirow[t]{8}{*}{$\mathrm{W}_{1}$} & $\mathrm{~T}_{1}$ & 80.00 & 150.67 & 124.00 & 116.00 & 14.47 & 44.93 & 52.34 & 54.98 & 0.00 & 0.00 & 0.00 & 0.00 \\
\hline & $\mathrm{T}_{2}$ & 0.00 & 2.67 & 5.33 & 5.33 & 0.00 & 1.29 & 1.54 & 1.75 & 100.00 & 98.81 & 98.63 & 98.43 \\
\hline & $\mathrm{T}_{3}$ & 26.67 & 38.67 & 34.67 & 32.00 & 3.71 & 13.82 & 18.93 & 22.77 & 74.47 & 71.40 & 68.8 & 65.06 \\
\hline & $\mathrm{T}_{4}$ & 22.67 & 36.00 & 32.00 & 32.00 & 3.01 & 12.41 & 16.61 & 20.41 & 79.29 & 74.54 & 70.83 & 69.84 \\
\hline & $\mathrm{T}_{5}$ & 22.67 & 32.00 & 28.00 & 28.00 & 2.16 & 10.09 & 15.19 & 18.34 & 85.06 & 80.25 & 76.78 & 73.86 \\
\hline & $\mathrm{T}_{6}$ & 20.00 & 24.00 & 20.00 & 20.00 & 2.08 & 6.70 & 9.95 & 9.82 & 85.90 & 86.31 & 80.86 & 78.78 \\
\hline & $\mathrm{T}_{7}$ & 16.00 & 28.00 & 26.00 & 20.00 & 1.28 & 8.25 & 11.66 & 15.05 & 91.27 & 83.76 & 78.8 & 80.14 \\
\hline & $\mathrm{T}_{8}$ & 16.00 & 20.00 & 16.00 & 16.00 & 1.23 & 5.03 & 7.78 & 9.27 & 91.68 & 88.85 & 80.6 & 82.57 \\
\hline \multirow[t]{8}{*}{$\mathrm{W}_{2}$} & $\mathrm{~T}_{1}$ & 109.33 & 186.67 & 164.00 & 144.00 & 19.67 & 55.61 & 64.63 & 67.26 & 0.00 & 0.00 & 0.00 & 0.00 \\
\hline & $\mathrm{T}_{2}$ & 0.00 & 4.00 & 5,33 & 6.67 & 0.00 & 1.79 & 2.42 & 2.53 & 100.00 & 98.50 & 97.47 & 97.23 \\
\hline & $\mathrm{T}_{3}$ & 37.33 & 54.67 & 49.33 & 44.00 & 6.12 & 18.68 & 25.29 & 27.95 & 69.02 & 68.46 & 62.52 & 61.58 \\
\hline & $\mathrm{T}_{4}$ & 33.33 & 46.67 & 40.00 & 36.00 & 5.15 & 16.61 & 22.67 & 24.76 & 74.05 & 72.22 & 67.5 & 67.26 \\
\hline & $\mathrm{T}_{5}$ & 24.67 & 42.00 & 36.00 & 34.00 & 3.98 & 15.66 & 21.13 & 23.14 & 79.96 & 74.61 & 71.12 & 71.72 \\
\hline & $\mathrm{T}_{6}$ & 28.00 & 32.00 & 29.33 & 28.00 & 3.96 & 11.62 & 16.77 & 21.04 & 80.05 & 80.39 & 76.68 & 75.74 \\
\hline & $\mathrm{T}_{7}$ & 24.00 & 36.00 & 32.00 & 34.00 & 2.96 & 13.16 & 18.46 & 21.07 & 85.24 & 78.42 & 72.60 & 70.52 \\
\hline & $\mathrm{T}_{8}$ & 22.67 & 28.00 & 24.00 & 26.00 & 2.85 & 9.52 & 14.59 & 16.45 & 85.76 & 82.96 & 82.33 & 78.37 \\
\hline \multicolumn{2}{|c|}{ LSD (0.05) } & 6.59 & 7.02 & 8.48 & 7.82 & 0.94 & 1.61 & 2.37 & 2.65 & 2.03 & 2.76 & 3.43 & 3.45 \\
\hline \multicolumn{2}{|l|}{ CV (\%) } & 9.91 & 12.81 & 10.31 & 11.02 & 10.35 & 12.28 & 11.08 & 10.76 & 6.64 & 7.11 & 7.28 & 8.06 \\
\hline
\end{tabular}

$\mathrm{W}_{1}=$ Good water management; $\mathrm{W}_{2}=$ Poor water management; $\mathrm{T}_{1}=$ No weeding $\left(\right.$ Control); $\mathrm{T}_{2}=$ Weed free; $\mathrm{T}_{3}=$ Two hand weedings at 25 and $40 \mathrm{DAT} ; \mathrm{T}_{4}=$ BRRI Weeder at 20 and $40 \mathrm{DAT} ; \mathrm{T}_{3}=$ Rifit500EC @ IL/ha at 7 DAT; $\mathrm{T}_{6}=$ Rifit 500LC @ IL/ha at 7 DAT and one hand weeding at 40 DAT, respectively; $\mathrm{T}_{7}=$ Butachlor 5G @ 2 kg/ha at 7 DAT; $\mathrm{T}_{5}=$ Butachlor 5G @ 2 kg/ha at 7 DAT and one hand weeding at $40 \mathrm{DAT}$, respectively. 
The highest weed density was observed in unweeded treatment under poor water management throughout the growing period (Table 2). Other than weed free treatment, the lowest weed density was observed in the treatment receiving Butachlor 5G @ 2kg/ha accompanied by one hand weeding at 40 DAT $\left(\mathrm{T}_{8}\right)$ under good water management. Similar trend was noticed in case of weed biomass since weed biomass is positively related to weed density. The higher the weed biomass, the lower the WCE irrespective of treatment. At the same time, weed control measures become more difficult as the crop canopy spreads from mid to later stages of crop growth. So, it might reasonably be argued that combination of several approaches like herbicide and hand weeding along with cultural practices like judicious water management might resulted in better weed control efficiency than any single approach either physical or chemical.

\section{Performance of transplanted aman rice}

Dry matter production (Above ground): The interaction effect between water management and weed control treatment was significant on total above ground dry matter (DM) production of the crop (Table 3). Data indicated that both water management and weed control treatments caused significant variations in DM production. Although the variation was non-significant at early growth stages (upto 30 DAT), however, significant variation was apparent at 45 DAT and onwards until the end of the season. Finally, the highest above ground DM $\left(1361.58 \mathrm{~g} / \mathrm{m}^{2}\right)$ was observed in the weed free treatment under good water management, while the lowest $\left(774.79 \mathrm{~g} / \mathrm{m}^{2}\right)$ was in the control plots under poor water management. Apart from weed free situation, the highest above ground DM $\left(1311.73 \mathrm{~g} / \mathrm{m}^{2}\right)$ was produced when the plots were treated with Butachlor 5G @ $2 \mathrm{~kg} / \mathrm{ha}$ along with one hand weeding at $40 \mathrm{DAT}\left(\mathrm{T}_{8}\right)$ under good water management, which was significantly superior to other weed control treatments.

Yield and yield contributing characters: Water management practices caused significant variations in terms of grain yield irrespective of weed control treatments (Table 4). Good water management contributed to superior performance over the poor one in terms of yield and yield contributing characters. Significant variation was also observed between weed control treatments within the same water management practice (Table 4). Among the treatments, the highest grain yield was recorded from good water management and weed free treatment $(5.22 \mathrm{t} / \mathrm{ha})$. This might be attributed to the highest number of effective tillers per $\mathrm{m}^{2}$, filled grains per panicle, heavier grains as well as lowest number of unfilled grains per panicle. The same treatment also contributed to higher grain yield in poor water management although $9.58 \%$ 
Table 3. Total dry matter (TDM) production of transplanted Aman rice as affected by water management and weed control treatments.

\begin{tabular}{|c|c|c|c|c|c|c|c|c|}
\hline \multirow{2}{*}{$\begin{array}{c}\text { Water } \\
\text { management }\end{array}$} & \multirow{2}{*}{$\begin{array}{c}\text { Weed } \\
\text { control } \\
\text { treatment }\end{array}$} & \multicolumn{7}{|c|}{ Total dry matter $\left(\mathrm{g} / \mathrm{m}^{2}\right)$} \\
\hline & & 15 DAT & 30 DAT & 45 DAT & 60 DAT & 75 DAT & 90 DAT & $\begin{array}{c}\text { At } \\
\text { Harvest }\end{array}$ \\
\hline \multirow[t]{8}{*}{$\mathrm{W}_{1}$} & $\mathrm{~T}_{1}$ & 38.00 & 140.00 & 328.54 & 565.76 & 831.17 & 958.77 & 978.26 \\
\hline & $\mathrm{T}_{2}$ & 48.12 & 172.33 & 403.69 & 749.65 & 1132.19 & 1319.77 & 1361.58 \\
\hline & $\mathrm{T}_{3}$ & 39.47 & 150.50 & 343.65 & 631.21 & 912.76 & 1063.61 & 1104.86 \\
\hline & $\mathrm{T}_{4}$ & 39.89 & 153.57 & 351.65 & 665.43 & 941.71 & 1092.85 & 1135.02 \\
\hline & $\mathrm{T}_{5}$ & 43.14 & 158.24 & 357.49 & 687.43 & 976.77 & 1128.19 & 1169.53 \\
\hline & $\mathrm{T}_{6}$ & 43.35 & 159.37 & 371.51 & 714.44 & 1051.26 & 1221.03 & 1267.35 \\
\hline & $\mathrm{T}_{7}$ & 46.28 & 167.81 & 378.35 & 705.40 & 1015.71 & 1167.38 & 1207.30 \\
\hline & $\mathrm{T}_{8}$ & 46.38 & 168.54 & 391.29 & 733.76 & 1087.71 & 1264.44 & 1311.73 \\
\hline \multirow[t]{8}{*}{$\mathrm{W}_{2}$} & $\mathrm{~T}_{1}$ & 35.12 & 102.36 & 238.51 & 456.62 & 675.92 & 764.78 & 774.79 \\
\hline & $\mathrm{T}_{2}$ & 45.27 & 146.39 & 355.41 & 691.77 & 1062.18 & 1243.58 & 1289.87 \\
\hline & $\mathrm{T}_{3}$ & 36.87 & 120.27 & 278.29 & 530.74 & 785.50 & 915.68 & 954.85 \\
\hline & $\mathrm{T}_{4}$ & 37.17 & 123.54 & 287.88 & 569.85 & 821.57 & 960.71 & 993.39 \\
\hline & $\mathrm{T}_{5}$ & 40.96 & 128.54 & 299.65 & 607.70 & 870.41 & 1008.27 & 1041.98 \\
\hline & $\mathrm{T}_{6}$ & 40.86 & 128.56 & 316.34 & 642.38 & 967.17 & 1119.62 & 1161.46 \\
\hline & $\mathrm{T}_{7}$ & 44.19 & 139.25 & 325.39 & 637.41 & 920.50 & 1069.23 & 1109.43 \\
\hline & $\mathrm{T}_{8}$ & 44.28 & 139.56 & 341.47 & 669.85 & 1019.02 & 1182.58 & 1231.22 \\
\hline LSD (0.05) & & & & 10.61 & 22.81 & 23.46 & 24.56 & 24.35 \\
\hline CV (\%) & & 7.09 & 8.84 & 9.89 & 11.13 & 10.36 & 12.23 & 11.29 \\
\hline
\end{tabular}

lower than in good water management. Apart from the weed free treatment, the highest grain yield (4.96 t/ha was obtained when the plot was treated with Butachlor 5G @ 2 kg/ha and one hand weeding (at 40 DAT), respectively $\left(\mathrm{T}_{8}\right)$ under good water management. Similar trends in yield components were also observed in this treatment. The same treatment under poor water management practice also produced the highest grain yield (4.48 t/ha other than weed free treatment, although $10 \%$ lower than under good water management. The lowest grain yield (1.91 t/ha) was recorded in unweeded treatment $\left(\mathrm{T}_{1}\right)$ under poor water management. When yield contributing characters were examined, it was found that all the yield components performed the worst with the highest number of unfilled grains per panicle in this treatment. It might be due to higher crop weed competition with limited resources in the treatment. Among the other treatments, Rifit 500EC @ 1L/ha and one hand weeding at 7 and 40 DAT, respectively $\left(\mathrm{T}_{6}\right)$ performed better followed by Butachlor 5G @2 kg/ha at 7 DAT $\left(\mathrm{T}_{7}\right)$, BRRI Weeder at 20 and $40 \mathrm{DAT}\left(\mathrm{T}_{4}\right)$. Two hand weedings at 25 and $40 \mathrm{DAT}\left(\mathrm{T}_{3}\right)$ 
produced lower yield compared to other treatments except unweeded treatment. Considering the results of the present study, it might be reasonably argued that Butachlor 5G @ $2 \mathrm{~kg} / \mathrm{ha}$ at $7 \mathrm{DAT}$ and one hand weeding at $40 \mathrm{DAT}\left(\mathrm{T}_{8}\right)$ might be considered as viable option for better performance of T. aman rice in terms of weed control efficiency (Table 2) grain yield (Table 4).

Table 4. Yield performance of transplanted aman rice as affected by water management and weed control treatment.

\begin{tabular}{l|c|c|c|c|c|c|c}
\hline $\begin{array}{c}\text { Water } \\
\text { management }\end{array}$ & $\begin{array}{c}\text { Weed } \\
\text { control } \\
\text { treatment }\end{array}$ & $\begin{array}{c}\text { Effective } \\
\text { tillers/m }\end{array}$ & $\begin{array}{c}\text { Filled } \\
\text { grains/ } \\
\text { panicle }\end{array}$ & $\begin{array}{c}\text { Unfilled } \\
\text { grains/ } \\
\text { panicle }\end{array}$ & $\begin{array}{c}1000- \\
\text { grain wt } \\
(\mathrm{g})\end{array}$ & $\begin{array}{c}\text { Grain } \\
\text { yield } \\
\text { (t/ha) }\end{array}$ & $\begin{array}{c}\text { Straw } \\
\text { yield } \\
\text { (t/ha) }\end{array}$ \\
\hline $\mathrm{W}_{1}$ & $\mathrm{~T}_{1}$ & 239.25 & 59.81 & 29.30 & 22.64 & 2.95 & 3.66 \\
& $\mathrm{~T}_{2}$ & 346.50 & 97.58 & 23.64 & 24.99 & 5.22 & 5.55 \\
& $\mathrm{~T}_{3}$ & 268.50 & 75.60 & 27.55 & 23.93 & 4.33 & 5.21 \\
& $\mathrm{~T}_{4}$ & 274.75 & 77.49 & 27.33 & 23.97 & 4.36 & 5.20 \\
& $\mathrm{~T}_{5}$ & 278.25 & 79.20 & 26.69 & 24.03 & 4.43 & 5.09 \\
& $\mathrm{~T}_{6}$ & 320.00 & 87.85 & 24.42 & 24.52 & 4.66 & 5.18 \\
& $\mathrm{~T}_{7}$ & 289.75 & 8.94 & 26.23 & 24.16 & 4.50 & 5.12 \\
& $\mathrm{~T}_{8}$ & 333.00 & 92.54 & 24.12 & 24.79 & 4.96 & 5.44 \\
\hline $\mathrm{W} 2$ & $\mathrm{~T}_{1}$ & 166.75 & 47.41 & 37.28 & 22.08 & 1.91 & 2.50 \\
& $\mathrm{~T}_{2}$ & 316.50 & 91.54 & 26.08 & 24.87 & 4.72 & 5.13 \\
& $\mathrm{~T}_{3}$ & 211.00 & 67.36 & 33.81 & 23.63 & 3.59 & 4.43 \\
& $\mathrm{~T}_{4}$ & 218.25 & 69.41 & 32.91 & 23.65 & 3.68 & 4.46 \\
& $\mathrm{~T}_{5}$ & 228.25 & 71.42 & 31.95 & 23.73 & 3.71 & 4.43 \\
& $\mathrm{~T}_{6}$ & 277.00 & 80.89 & 28.82 & 24.32 & 4.08 & 4.64 \\
& $\mathrm{~T}_{7}$ & 244.75 & 76.56 & 30.49 & 23.92 & 3.86 & 4.54 \\
& $\mathrm{~T}_{8}$ & 298.00 & 86.18 & 27.04 & 24.63 & 4.48 & 4.96 \\
\hline $\mathrm{LSD}(0.05)$ & & 14.43 & 2.14 & 1.05 & $\mathrm{~ns}$ & 0.22 & 0.29 \\
& & 9.34 & 9.88 & 8.20 & 4.38 & 9.25 & 10.70 \\
\hline
\end{tabular}

Results indicated that weed control efficiency of different weed control practices had decisive bearing on weed density and weed biomass leading to better weed control efficiency, which was ultimately manifested in better grain yield irrespective of water management practice. The higher was the weed control efficiency, the lower was the weed density as well as weed biomass (Table 2). The ultimate impact was the higher yield (Table 4). Finally, it might reasonably be argued that integration of approaches rather than single one could solve the weed problem in transplanted aman rice substantially leading to satisfactory yield. In this context, herbicide application along with one. But before that, water management should be considered as the primary means of 
weed suppression since proper water management contributed to $17.91 \%$ higher grain yield compared to poor water management irrespective of weed control measures. Even combination of Butachlor 5G @ 2 kg/ha with one hand weeding at $40 \mathrm{DAT}\left(\mathrm{T}_{8}\right)$ also contributed to more than $10 \%$ higher grain yield under good water management over the same under poor water management. Jafari and Moussavi (1993) found that with continuous water flow Thiobencarb, Piperophos and Butachlor were the most effective herbicides and highest yield were obtained with Piperophos followed by Butachlor, Oxadiazone, Thiobencarb and Molinate. respectively. Phogat et al. (1998) also reported that water regimes significantly affected increase in grain yield under herbicide treatment. However, economic feasibility of herbicide application as well as environmental implications of continuous and longer term use of herbicides in rice fields should be addressed properly in future research programmes.

\section{References}

Ahmed, G.J.U., A. A. Mamun, S.M.A. Hossain, A.J. Mridha and S.T. Hossain. 2000. Agro-economic study of weed control in direct seeded us rice in the farmers' field. Ann. Bangladesh Agric. 8(2): 111-118.

BBS. 2005. Statistical Yearbook of 2004. Bangladesh Bureau of Statistics, Ministry of Planning, Dhaka.

Gill, P.S., B.S. Bhangoo and B.S. Boparai. 1992. Weed control efficacy of tridiphane and fluroxypyr in transplanted rice (Oryza sativa). Indian J.Agron. 37(3): 573-575.

Hossain, S.M.A. 2006. Personal communication. Professor, Dept. of Agronomy, Bangladesh Agricultural University, Mymensingh.

Islam, M.A. 2001. Evaluation of four herbicides in controlling weeds in transplanted aman rice. Unpublished Thesis. Bangladesh Agricultural University, Mymensingh. pp. 3 5-64.

Jafari, M.E. and M.R. Moussavi. 1993. Evaluation of post application water management on the effectiveness of herbicides in rice paddy field in Mazandaran. Integrated weed management for sustainable agriculture. Proc. Indian Soc. Weed Sci. International Symposium, Hisar, India, 18-20 November 1993. Vol. II, 155-157.

Mamun, A.A. 1990. Weeds and their control: A review of weed research in Bangladesh. Agricultural and Rural Development in Bangladesh.. Japan Intl. Co-operation agency. Dhaka, Bangladesh. JSARD. Pub. No. 19. pp. 45-72.

Mamun, A.A. 1988. Farmers' concepts of weeds and weed control in Jawar village in Kishoregonj. Agricultural and Rural Development in Bangladesh. Japan Intl. Cooperation Agency, Dhaka, Bangladesh. JSARD Pub. No 8. pp. 77-78.

Mondol, M.A.H., M.A. Rahman and M.A. Gaffar. 1995. Field efficacy of Rilof H and Rifit herbicides for weed control in transplanted aman rice (BRI1). Bangladesh $J$. Agric. 19(20): 7-12. 
Nandal, D.P. and C.M. Singh. 1994. Effect of weed control on direct seeded puddled rice. Haryana Agril. Univ. J. Res. 24(4): 154-157.

Panwar, R.S., R.K. Malik and R.S. Malik. 1992. Effect of weedicides on weed control in wheat (Tritichum aestivum) crop. Indian J. Agron. 37(2): 320-323.

Phogat, B.S., Jitendra Pandey and J. Pandey. 1998. Effect of water regime and weed control on weed flora and yield of transplanted rice (Oryza sativa). Indian Journal of Agronomy 43(1): 77-81.

Rahman, S.M. 2001. Effect of herbicides on the growth and yields of aus rice cv. Iratom24. Unpublished Thesis. Bangladesh Agricultural University, Mymensingh. pp. 45-66. 